Article

\title{
Antibacterial Effects of Bicarbonate in Media Modified to Mimic Cystic Fibrosis Sputum
}

\author{
Pongsiri Jaikumpun ${ }^{1}{ }^{(0)}$, Kasidid Ruksakiet ${ }^{1,2}$, Balázs Stercz ${ }^{3}{ }^{\circledR}$, Éva Pállinger ${ }^{4}$, \\ Martin Steward ${ }^{1,5}{ }^{(0}$, Zsolt Lohinai ${ }^{2}{ }^{(0)}$, Orsolya Dobay ${ }^{3}$ and Ákos Zsembery ${ }^{1, *}$ \\ 1 Department of Oral Biology, Semmelweis University, H-1089 Budapest, Hungary; pongsirij@nu.ac.th (P.J.); \\ ksd13rsk@gmail.com (K.R.); martin.steward@manchester.ac.uk (M.S.) \\ 2 Department of Conservative Dentistry, Semmelweis University, H-1088 Budapest, Hungary; \\ lohinai.zsolt@dent.semmelweis-univ.hu \\ 3 Institute of Medical Microbiology, Semmelweis University, H-1089 Budapest, Hungary; \\ stercz.balazs@med.semmelweis-univ.hu (B.S.); dobay.orsolya@med.semmelweis-univ.hu (O.D.) \\ 4 Institute of Genetics, Cell, and Immunobiology, Semmelweis University, H-1089 Budapest, Hungary; \\ eva.pallinger@gmail.com \\ 5 School of Medical Sciences, University of Manchester, Manchester M13 9PL, UK \\ * Correspondence: zsembery.akos@dent.semmelweis-univ.hu
}

Received: 8 October 2020; Accepted: 14 November 2020; Published: 16 November 2020

check for updates

\begin{abstract}
Cystic fibrosis (CF) is a hereditary disease caused by mutations in the gene encoding an epithelial anion channel. In $\mathrm{CF}, \mathrm{Cl}^{-}$and $\mathrm{HCO}_{3}{ }^{-}$hyposecretion, together with mucin hypersecretion, leads to airway dehydration and production of viscous mucus. This habitat is ideal for colonization by pathogenic bacteria. We have recently demonstrated that $\mathrm{HCO}_{3}{ }^{-}$inhibits the growth and biofilm formation of Pseudomonas aeruginosa and Staphylococcus aureus when tested in laboratory culture media. Using the same bacteria our aim was to investigate the effects of $\mathrm{HCO}_{3}{ }^{-}$in artificial sputum medium (ASM), whose composition resembles CF mucus. Control ASM containing no $\mathrm{NaHCO}_{3}$ was incubated in ambient air (pH 7.4 or 8.0). ASM containing $\mathrm{NaHCO}_{3}(25$ and $100 \mathrm{mM}$ ) was incubated in 5\% $\mathrm{CO}_{2}$ (pH 7.4 and 8.0, respectively). Viable P. aeruginosa and S. aureus cells were counted by colony-forming unit assay and flow cytometry after $6 \mathrm{~h}$ and $17 \mathrm{~h}$ of incubation. Biofilm formation was assessed after $48 \mathrm{~h}$. The data show that $\mathrm{HCO}_{3}{ }^{-}$significantly decreased viable cell counts and biofilm formation in a concentration-dependent manner. These effects were due neither to extracellular alkalinization nor to altered osmolarity. These results show that $\mathrm{HCO}_{3}{ }^{-}$exerts direct antibacterial and antibiofilm effects on prevalent CF bacteria.
\end{abstract}

Keywords: cystic fibrosis; chronic inflammation; bacteria; biofilm; mucus; bicarbonate; $\mathrm{pH}$

\section{Introduction}

Cystic fibrosis (CF) is a genetic disease caused by mutations in the gene encoding cystic fibrosis transmembrane conductance regulator (CFTR) protein [1]. CFTR is an epithelial anion channel that primarily mediates chloride and bicarbonate ion secretion [2,3]. In some epithelia, it may also regulate sodium absorption via the epithelial sodium channel (ENaC) [4]. These functions are essential for regulating fluid movement across multiple epithelial surfaces in the body. Therefore, mutations in this channel protein result in multiple-organ dysfunction, which profoundly affects the life expectancy of CF patients [5].

Chronic lung disease is the leading cause of death in CF patients. In the CF lung, CFTR dysfunction causes a decrease in $\mathrm{Cl}^{-}$and $\mathrm{HCO}_{3}{ }^{-}$secretion, and an increase in $\mathrm{Na}^{+}$absorption, resulting in dehydration and acidification of the airway surface liquid (ASL). This abnormal ASL constantly hampers 
the mucociliary clearance mechanism (MCC) and compromises the immune defenses of the airways [6]. The formation of thick and sticky mucus creates ideal conditions for bacterial colonization [7]. The most common bacteria in CF lungs are Pseudomonas aeruginosa, Staphylococcus aureus, Haemophilus influenzae, and Burkholderia cepacia $[8,9]$. These bacteria easily form biofilms, which significantly increase their resistance to antibiotics. Since the eradication of bacterial biofilms is extremely difficult, chronic airway inflammation and lung damage frequently occur in CF [10].

Failure of $\mathrm{HCO}_{3}{ }^{-}$secretion could be of critical importance in $\mathrm{CF}[5,11]$. In normal conditions, mucus secretion requires $\mathrm{HCO}_{3}{ }^{-}$to release and unfold mucin molecules by raising $\mathrm{pH}$ and removing $\mathrm{Ca}^{2+}[12]$. In a piglet trachea model, insufficient $\mathrm{HCO}_{3}{ }^{-}$secretion has been shown to cause defective mucus homeostasis [13]. A more recent study showed that CF airway abnormalities in the CFTR-knockout rat could be reversed by $\mathrm{HCO}_{3}{ }^{-}$[14]. Garcia et al. reported that $\mathrm{PGE}_{2}$ or 5-HT stimulated mucus release was reduced by approximately one half in the absence of $\mathrm{HCO}_{3}{ }^{-}$[15]. Moreover, mucus on the ileal mucosa of the CF mouse was denser and thicker than in the wild-type mouse. However, the abnormal properties of this mucus could be corrected by $\mathrm{NaHCO}_{3}$ supplementation [16]. Sodium bicarbonate also restores airway bacterial killing capacity in vivo [17], and we have shown that $\mathrm{NaHCO}_{3}$ is beneficial to $\triangle$ F508-CFTR expressing-CFBE cells [18]. The administration of $\mathrm{NaHCO}_{3}$ is clearly a promising therapeutic approach for treating CF lung disease.

We have recently demonstrated that adding $\mathrm{HCO}_{3}{ }^{-}$inhibits the growth of planktonic $\mathrm{CF}$ pathogens and the formation of P. aeruginosa biofilms in conventional microbiological media [19]. However, a number of studies suggest that the microbiological media are designed to be convenient, rather than to resemble the complexity of the host environment $[20,21]$. In the CF lung, ASL has a unique composition that could influence bacterial behavior significantly [22]. We have therefore tested the effects of $\mathrm{HCO}_{3}{ }^{-}$on bacterial growth and biofilm formation in an artificial sputum medium (ASM) that mimics the properties of ASL in CF patients $[20,22,23]$. Our data show that both bacterial growth and biofilm formation are inhibited by $\mathrm{HCO}_{3}{ }^{-}$in a concentration-dependent manner.

\section{Results}

\subsection{Sodium Bicarbonate Inhibits the Growth of S. aureus and P. aeruginosa in Artificial Sputum Medium}

\subsubsection{Colony-Forming Unit Assays}

The inclusion of $100 \mathrm{mM} \mathrm{NaHCO}_{3}$ in the ASM ( $\mathrm{pH}$ 8.0) resulted in a significant reduction in viable cell counts for both $S$. aureus and P. aeruginosa after a $6 \mathrm{~h}$ incubation when compared to $\mathrm{NaHCO}_{3}$-free ASM at the same $\mathrm{pH}$ (Figure 1A-D). With $25 \mathrm{mM} \mathrm{NaHCO}_{3}$ in the ASM (pH 7.4) only the P. aeruginosa ATCC 27853 cell counts were significantly reduced (Figure 1C). Similar inhibitory effects of $100 \mathrm{mM}$ $\mathrm{NaHCO}_{3}$ on S. aureus and P. aeruginosa growth were observed after a $17 \mathrm{~h}$ incubation (Figure $1 \mathrm{E}-\mathrm{H}$ ), whereas $25 \mathrm{mM} \mathrm{NaHCO}_{3}$ caused count reductions for P. aeruginosa in both the ATCC strain and the clinical isolate (Figure 1G,H).

The count reduction caused by $100 \mathrm{mM} \mathrm{NaHCO}_{3}$ after $6 \mathrm{~h}$ was significantly greater than that caused by $25 \mathrm{mM} \mathrm{NaHCO}_{3}$ (with the single exception of the $S$. aureus ATCC strain), suggesting a concentration-dependent inhibitory effect of $\mathrm{HCO}_{3}{ }^{-}$on bacterial growth (Figure 1B-D). After the longer $17 \mathrm{~h}$ incubation, there were no significant differences between the inhibitory effects of 25 and $100 \mathrm{mM} \mathrm{NaHCO}_{3}$ in either species (Figure 1E-H).

To test whether these inhibitory effects could be attributed to the differences in $\mathrm{pH}$ of the $\mathrm{NaHCO}_{3}$-containing media, bacterial counts were compared in $\mathrm{NaHCO}_{3}$-free ASM at the same two $\mathrm{pH}$ values: 7.4 and 8.0. Data from S. aureus showed that, in the absence of $\mathrm{NaHCO}_{3}$, the more alkaline $\mathrm{pH}$ 8.0 medium did not reduce the cell counts compared to pH 7.4 (Figure 1A,B,E). Interestingly, the counts were actually increased at $\mathrm{pH} 8.0$ in the $\mathrm{S}$. aureus clinical isolate following the $17 \mathrm{~h}$ incubation (Figure $1 \mathrm{~F}$ ). On the other hand, the more alkaline $\mathrm{pH}$ slightly reduced the cell count for the P. aeruginosa ATCC strain after the $6 \mathrm{~h}$ incubation (Figure 1C), whereas no difference in effect was detected following the longer $17 \mathrm{~h}$ incubation (Figure 1G) or in the clinical isolate, regardless of incubation time (Figure 1D,H). 
Taken together, our data suggest that $\mathrm{NaHCO}_{3}$ has a concentration-dependent inhibitory effect on bacterial growth, which is not due to the accompanying changes in external $\mathrm{pH}$.
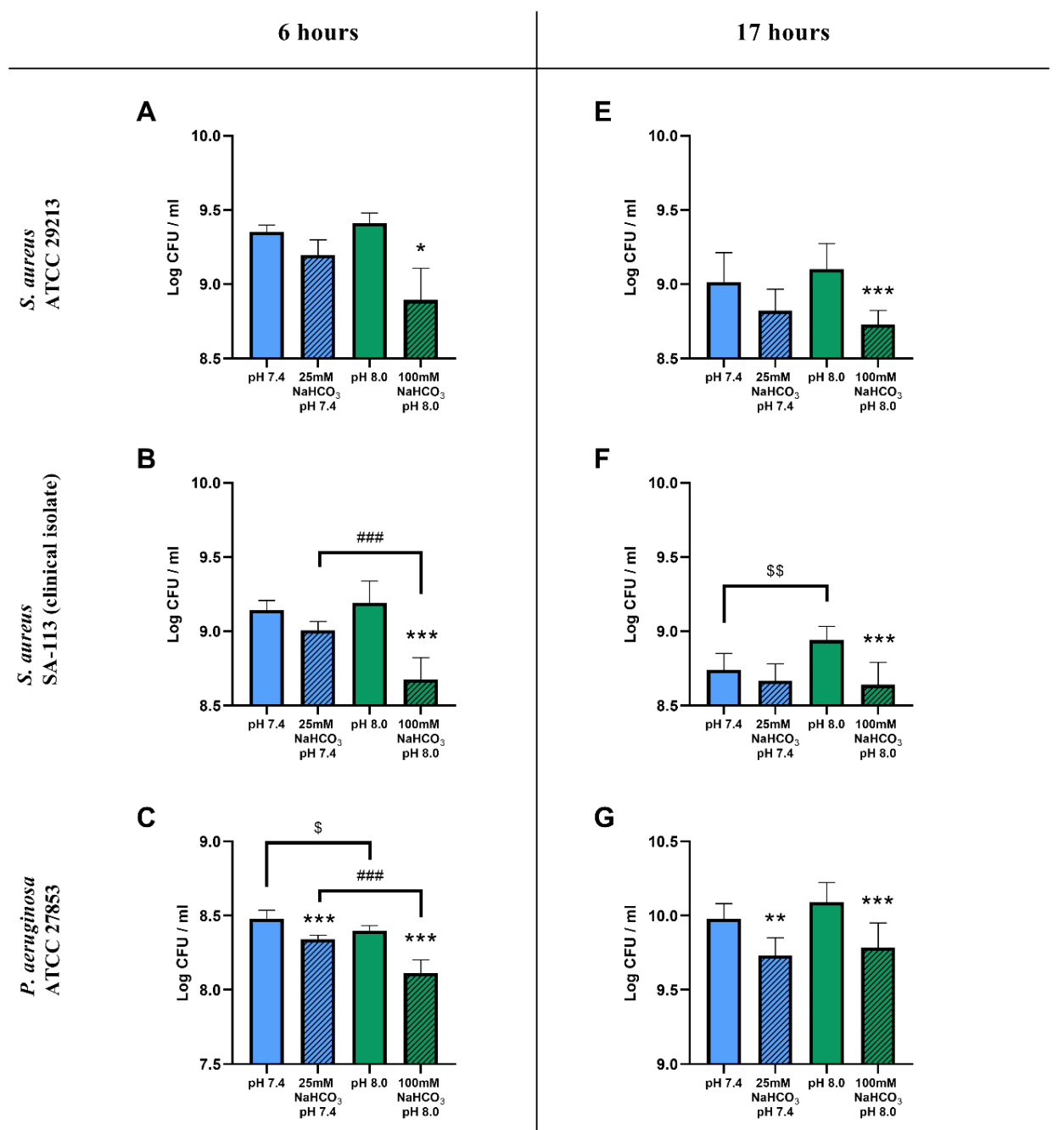

G


Figure 1. CFU assay of cystic fibrosis bacteria: S. aureus ATCC 29213 (A,E), S. aureus SA-113 (B,F), P. aeruginosa ATCC $27853(\mathbf{C}, \mathbf{G})$, and P. aeruginosa 17808 (D,H) grown in different ASM conditions for $6(\mathrm{~A}-\mathrm{D})$ and $17 \mathrm{~h}(\mathrm{E}-\mathrm{H})$ in ambient air or $5 \% \mathrm{CO}_{2}$. Values are presented as means of $\log \mathrm{CFU} / \mathrm{mL} \pm \mathrm{SD}$. The experiment was repeated three times. All data were pooled, totaling 9 replicates per treatment group, except for S. aureus ATCC at $6 \mathrm{~h}$ having only 3 replicates (A). Statistical analysis: one-way ANOVA followed by Tukey's post-hoc multiple comparison test (B-H) or Kruskal-Wallis test followed by Dunn's post-hoc multiple comparison test (A). ${ }^{*}=p<0.05,{ }^{* *}=p<0.01,{ }^{* * *}=p<0.001$ when comparing ASM with and without $\mathrm{NaHCO}_{3}$ at the same $\mathrm{pH}$ (same-colored columns); \#\# = $p<0.01$, $\# \#=p<0.001$ when comparing the two $\mathrm{NaHCO}_{3}$ concentrations ( 25 vs. $100 \mathrm{mM}$ ) (shaded columns); $\$=p<0.05, \$ \$=p<0.01$ when comparing $\mathrm{NaHCO}_{3}$-free $\mathrm{ASM}$ at $\mathrm{pH} 7.4$ and 8.0 (clear columns). 


\subsubsection{Flow Cytometric Assays}

We used flow cytometric techniques to examine the effects of $\mathrm{NaHCO}_{3}$ on the membrane integrity of the S. aureus and P. aeruginosa ATCC strains grown in ASM (Figure 2). When the bacteria were treated with propanol $(70 \%(v / v))$, propidium iodide (PI) entered the cells and induced strong red signals (R-2) while the SYTO9 green signals (R-3) were invisible (Figure 2A,F), indicating that, as expected, membrane damage is linked with an increase in PI and a decrease in SYTO9 signals.

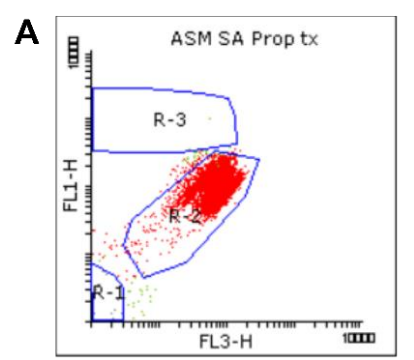

B

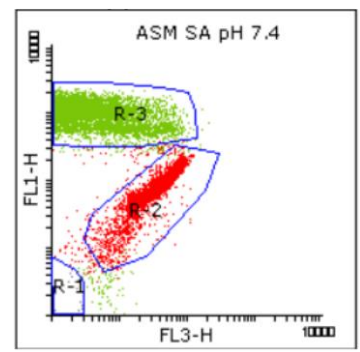

D

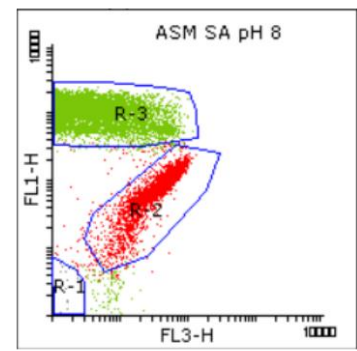

S. aureus ATCC 29213
C

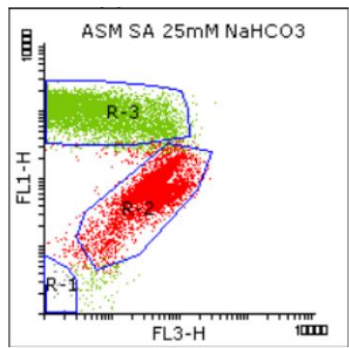

E



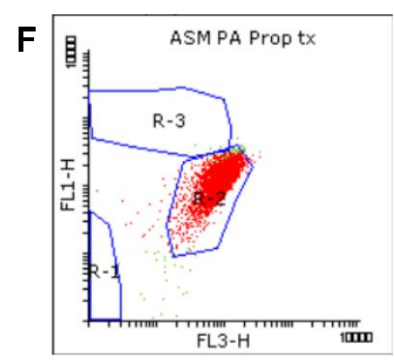
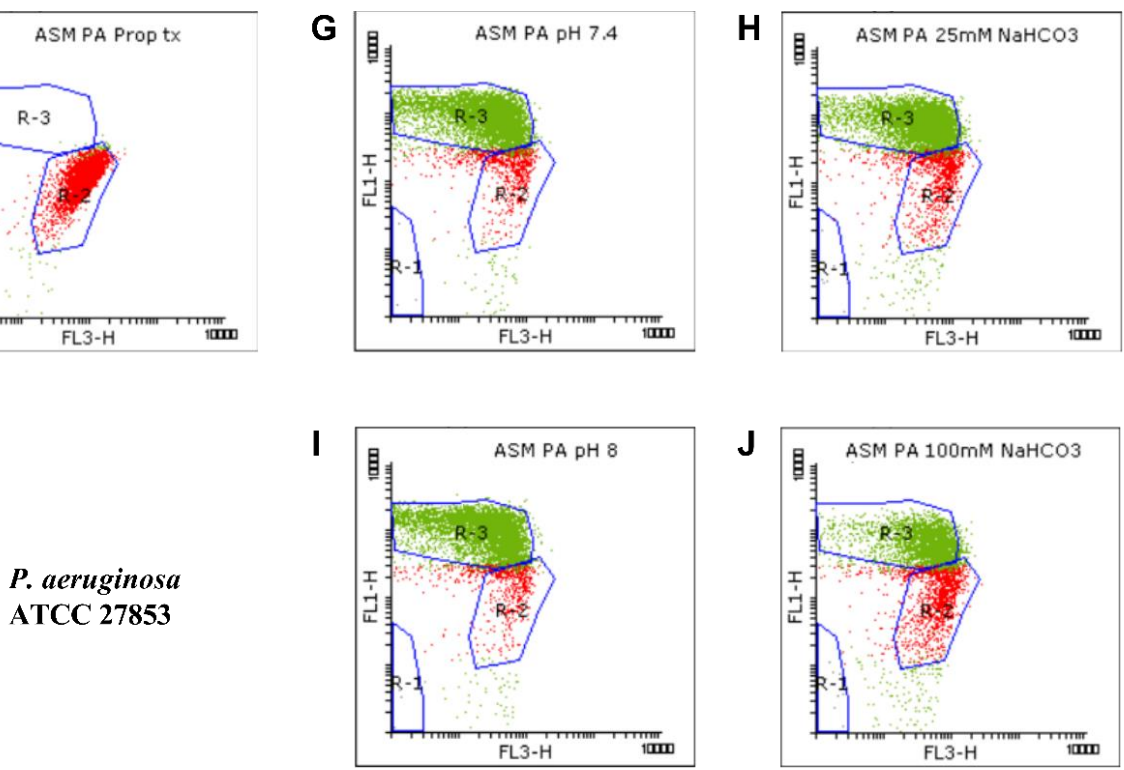

Figure 2. Viability staining for analyzing the growth of S. aureus (SA) ATCC 29213 (A-E) and P. aeruginosa (PA) ATCC 27853 (F-J). Bacteria were cultured in ASM and treated with 70\% propanol for membrane permeabilization (A,F), in $\mathrm{NaHCO}_{3}$-free ASM (pH 7.4) (B,G), in ASM containing $25 \mathrm{mM} \mathrm{NaHCO}_{3}$ (pH 7.4) (C,H), in $\mathrm{NaHCO}_{3}$-free ASM (pH 8.0) (D,I), and in ASM containing $100 \mathrm{mM} \mathrm{NaHCO}_{3}(\mathrm{pH}$ 8.0) $(\mathrm{E}, \mathrm{J})$. Bacterial signals from each condition are plotted as dot plots (FL1 vs. FL3). SYTO9-positive (green), PI-positive (red), and autofluorescence signals were gated in R-3, R-2, and R-1, respectively. 
We detected changes in both the density and shape of the clusters for the SYTO9 and PI signals when $\mathrm{NaHCO}_{3}$ was present in the ASM (Figure $2 \mathrm{C}, \mathrm{E}, \mathrm{H}, \mathrm{J}$ ) compared to $\mathrm{NaHCO}_{3}$-free conditions at the same $\mathrm{pH}$ (Figure 2B,D,G,I). Both 25 and $100 \mathrm{mM} \mathrm{NaHCO}_{3}$ enhanced the intensity of the PI signals, indicating that $\mathrm{NaHCO}_{3}$ increased the bacterial membrane permeability.

Percentages of SYTO9- and PI-positive cells were compared for ASM with and without $\mathrm{NaHCO}_{3}$ at different $\mathrm{pH}$ values (Figure 3). Incubation with $100 \mathrm{mM} \mathrm{NaHCO}_{3}(\mathrm{pH}$ 8.0) significantly reduced the percentage of SYTO9-positive cells, for both S. aureus and P. aeruginosa, when compared to $\mathrm{NaHCO}_{3}$-free ASM at the same $\mathrm{pH}$ (Figure 3A,C). Conversely, the percentage of PI-positive cells was increased in $100 \mathrm{mM} \mathrm{NaHCO}_{3}$, for both species, when compared to $\mathrm{NaHCO}_{3}$-free ASM at the same $\mathrm{pH}$ (Figure 3B,D). In addition, comparing the effects of $25 \mathrm{mM}$ and $100 \mathrm{mM} \mathrm{NaHCO}_{3}$, we observed a concentration-dependent decrease in the percentage of SYTO9-positive S. aureus cells (Figure 3A). It is of note that in P. aeruginosa, $25 \mathrm{mM} \mathrm{NaHCO}_{3}$ significantly increased the percentage of PI-positive cells (Figure 3D). Furthermore, the ratio of SYTO9- to PI-positive cells remained unchanged in ASM without $\mathrm{NaHCO}_{3}$ when the $\mathrm{pH}$ values were increased from 7.4 to 8.0 (Figure 4). These data indicate that the effects of $\mathrm{NaHCO}_{3}$ were not attributable to the alkalinization of extracellular milieu.

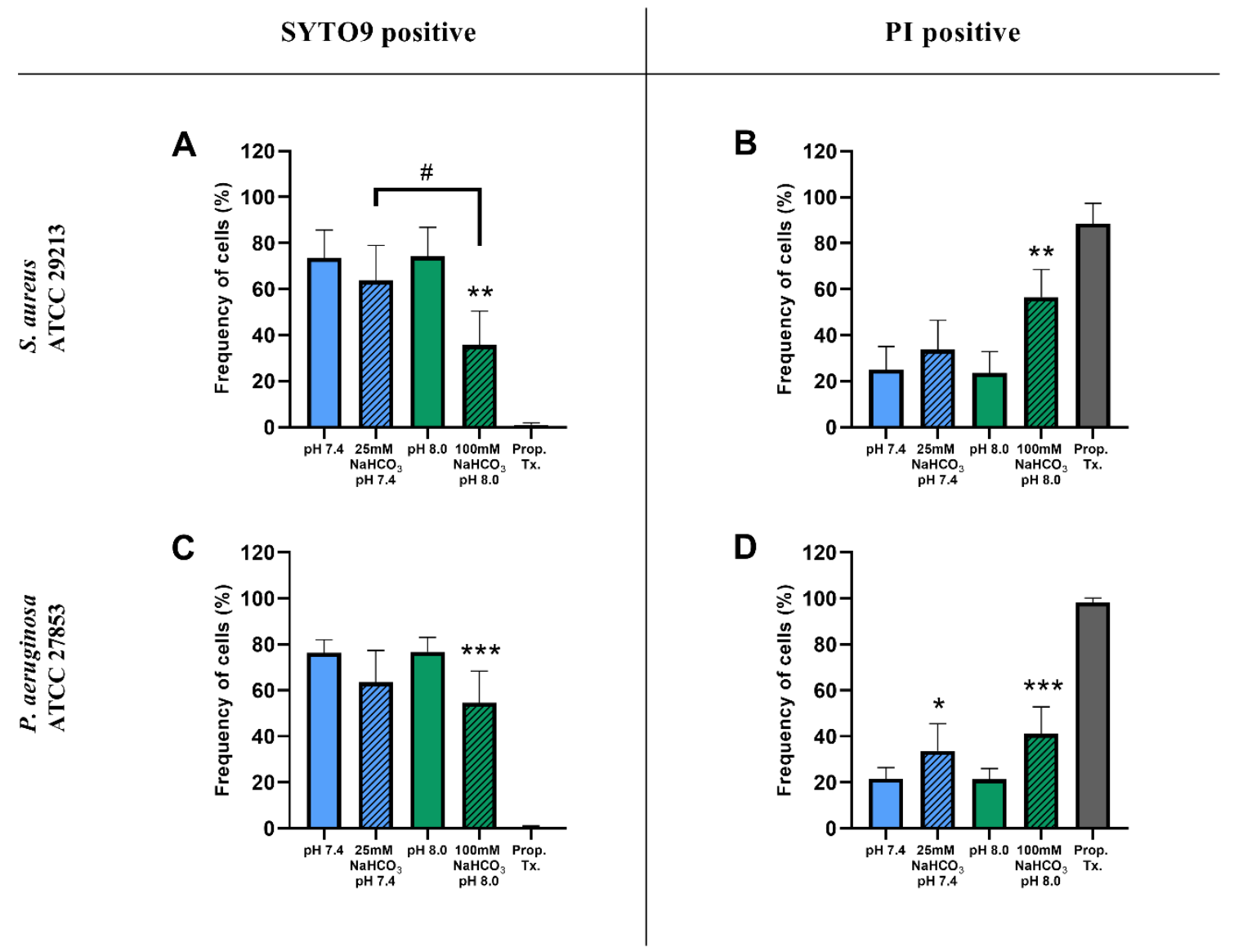

Figure 3. Percentage of SYTO9- and PI-positive signals of S. aureus ATCC 29213 (A,B) and P. aeruginosa ATCC 27853 (C,D) cells grown in different ASM after $17 \mathrm{~h}$ of incubation. Values are presented as percentage means $\pm \mathrm{SD}$. The experiment was repeated three (P. aeruginosa) or four times (S. aureus), totaling 9-12 replicates per treatment group. Statistical analysis: one-way ANOVA followed by Tukey's post-hoc multiple comparison test. ${ }^{*}=p<0.05,{ }^{* *}=p<0.01,{ }^{* * *}=p<0.001$ when comparing ASM with and without $\mathrm{NaHCO}_{3}$ at the same $\mathrm{pH}$ (same-colored columns); \# $=p<0.05$ when comparing the two $\mathrm{NaHCO}_{3}$ concentrations (25 vs. $100 \mathrm{mM}$ ) (shaded columns). 
A

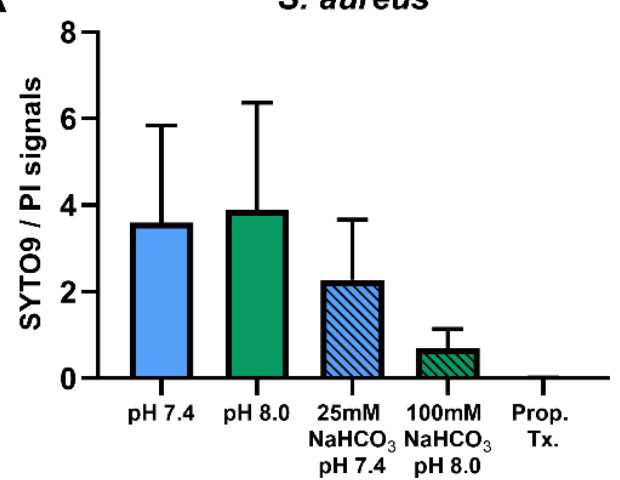

B



Figure 4. Ratios of SYTO9- to PI-positive signals of S. aureus ATCC $29213(n=4)($ A) and P. aeruginosa ATCC $27853(n=3)(\mathbf{B})$ in different ASM media. Values are presented as means \pm SD.

\subsection{Sodium Bicarbonate Inhibits Biofilm Formation by P. aeruginosa in ASM}

We have demonstrated that biofilm formation by P. aeruginosa can be inhibited by both 50 and $100 \mathrm{mM} \mathrm{NaHCO} 3$ in conventional bouillon medium [19]. Here, we investigated whether these inhibitory effects are also observed in ASM. P. aeruginosa 17808 (clinical isolate) was grown in ASM for $48 \mathrm{~h}$, after which biofilm formation capacity was assessed by crystal violet staining. Inclusion of both 25 and $100 \mathrm{mM} \mathrm{NaHCO}_{3}$ in the ASM inhibited biofilm formation significantly compared with the $\mathrm{NaHCO}_{3}$-free ASM at the same $\mathrm{pH}$ values (Figure 5A,B). Interestingly, the more alkaline external $\mathrm{pH}$ actually increased biofilm formation in $\mathrm{NaHCO}_{3}$-free $\mathrm{ASM}$ (Figure $5 \mathrm{~B}$, clear columns), reinforcing the conclusion that it cannot be the high $\mathrm{pH}$ that causes the strong inhibitory effects of $100 \mathrm{mM} \mathrm{HCO}_{3}^{-}$on bacterial growth.
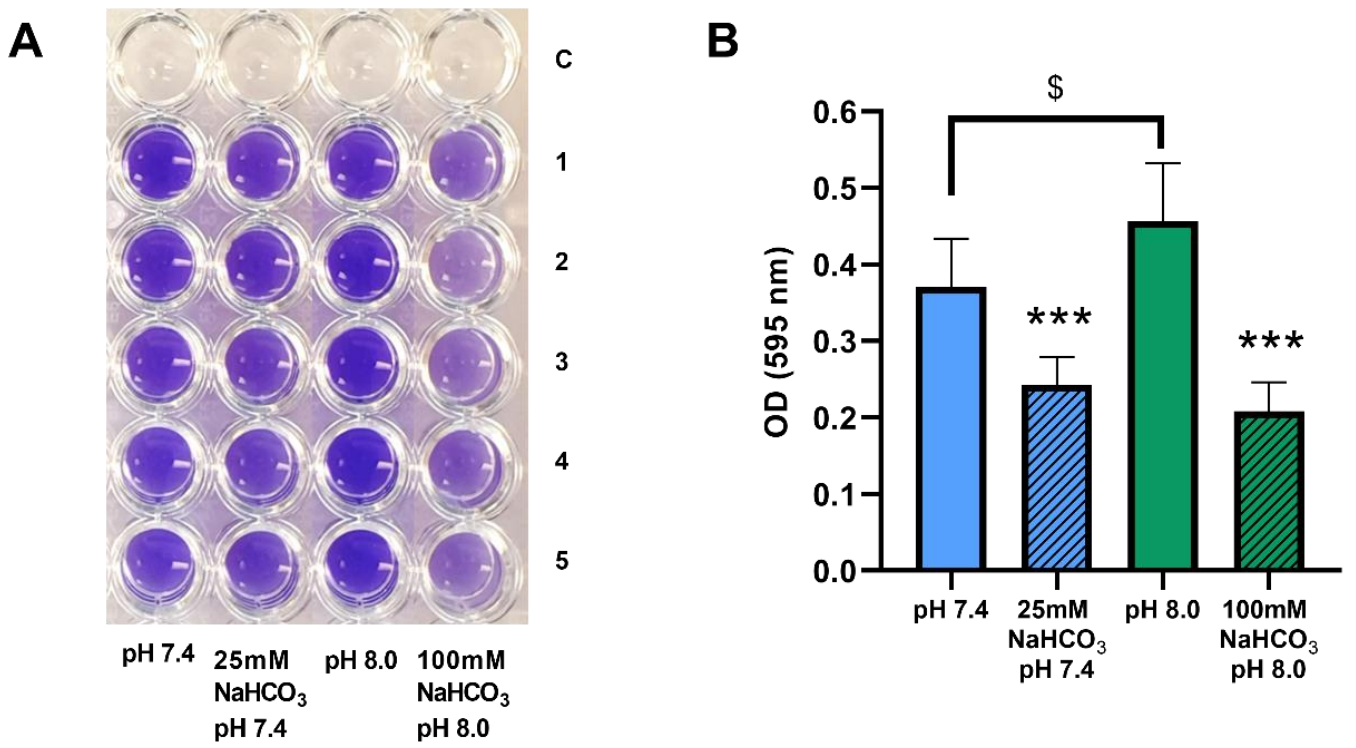

Figure 5. Biofilm formation by P. aeruginosa 17808 (clinical isolate) grown in different ASM. (A) crystal violet staining after $48 \mathrm{~h}$ of incubation. (B) statistical analysis of biofilm formation. Values are presented as means of optical density $(\mathrm{OD}) \pm \mathrm{SD}$. The experiment was repeated three times ( $n=3,15$ replicates per treatment group). Statistical analysis: one-way ANOVA followed by Tukey's post-hoc multiple comparison test. ${ }^{* * *}=p<0.001$ when comparing ASM with and without $\mathrm{NaHCO}_{3}$ at the same $\mathrm{pH}$ (same-colored columns); $\$=p<0.05$ when comparing the $\mathrm{NaHCO}_{3}$-free ASM at $\mathrm{pH} 7.4$ and 8.0 (clear columns). 


\section{Discussion}

In this study, we used a customized artificial sputum medium to investigate the effects of $\mathrm{HCO}_{3}{ }^{-}$ on growth and biofilm formation by CF-related bacteria. We found that (i) $\mathrm{HCO}_{3}{ }^{-}$inhibits the growth of both $P$. aeruginosa and $S$. aureus in a concentration-dependent manner, (ii) the inhibitory effects are probably related to bacterial membrane damage induced by $\mathrm{HCO}_{3}{ }^{-}$and (iii) $\mathrm{HCO}_{3}{ }^{-}$inhibits biofilm formation by $P$. aeruginosa. All of these effects were due to $\mathrm{HCO}_{3}{ }^{-}$per se and not to changes in external $\mathrm{pH}$ or osmolarity.

Previous studies have pointed out the critical significance of impaired $\mathrm{HCO}_{3}{ }^{-}$transport in $\mathrm{CF}$ pathology $[5,11,13-17,19]$. Defective $\mathrm{HCO}_{3}{ }^{-}$secretion contributes to the dehydration and acidification of the ASL, impaired mucociliary clearance, and mucus accumulation, all of which provide ideal conditions for bacterial colonization $[7,8]$. To mimic this environment, a special medium (ASM) was developed that may help to better understand the bacterial behavior in CF airways [20,22]. The effects of each ASM component were studied on the behavior of $P$. aeruginosa. It has been shown that mucin, eukaryotic DNA, amino acids, iron chelator, lecithin, and salts were required for the formation of tight micro-colonies [22]. Thomas et al. have also demonstrated that sputum amino acid concentrations correlate with the severity of CF lung disease [24]. Most CF pathogens grown in ASM show their normal characteristics, including specific gene expression, strong micro-colony formation, metabolite utilization, surface motility, evolutionary diversity and, most importantly, rigorous antibiotic resistance, which likely reflect the real pathological situation in the lung $[20,22,23,25-30]$. Thus, the accumulated evidence confirms the suitability of ASM for microbiological CF research.

Our data show that $100 \mathrm{mM} \mathrm{HCO}_{3}{ }^{-}$inhibits the growth of both S. aureus and P. aeruginosa in ASM as assessed by CFU assay. These inhibitory effects were observed following both 6- and 17-h incubations, indicating that bacterial growth was hampered both in exponential and stationary phases. These findings are in accordance with previous observations demonstrating the antimicrobial effects of $\mathrm{NaHCO}_{3}$ [19,31-33]. Corral and colleagues reported that $120 \mathrm{mM} \mathrm{NaHCO}_{3}$ reduces the CFU counts of E. coli, L. plantarum, S. aureus and P. aeruginosa 10,000-fold. This effect is more pronounced in yeasts such as S. cerevisiae and $\mathrm{H}$. wingei, with 100,000 -fold growth reductions induced by $60 \mathrm{mM} \mathrm{NaHCO} 3$ [31]. More recently, it has been demonstrated that $\mathrm{NaHCO}_{3}$ has antimicrobial effects on $E$. coli when applied in concentrations higher than $25 \mathrm{mM}$ [32]. Our previous work has also shown that the growth of common $\mathrm{CF}$ bacteria is inhibited in brain-heart infusion (BHI) media containing $\mathrm{NaHCO}_{3}$ [19].

Flow cytometry can be used in combination with nucleic acid double-staining (NADS) for viability determination based on bacterial membrane integrity [34]. Our data shows that ASM containing $100 \mathrm{mM} \mathrm{NaHCO}_{3}$ significantly increases the percentage of damaged cells, while alkalinization of the medium per se (from pH 7.4 to 8.0) has no effect on S. aureus (a Gram-positive bacterium). Repeating these experiments with P. aeruginosa was not at first successful because the percentage of SYTO9-positive cells remained very low even under control conditions. Other studies have reported the same phenomenon when flow cytometry and live/dead staining is used with Gram-negative bacteria [35-37]. The outer membrane of these bacteria constitutes a significant barrier to SYTO9 permeation. However, Berney and colleagues have shown that an appropriate dose of UVA light or EDTA $(5 \mathrm{mM})$ can weaken the outer membrane and allow SYTO9 uptake [36]. Indeed, when treating the cells with EDTA (5 mM), we were able to demonstrate that $100 \mathrm{mM} \mathrm{HCO}_{3}{ }^{-}$has inhibitory effects on $P$. aeruginosa similar to those we observed on S. aureus. These results confirm the antimicrobial properties of $\mathrm{NaHCO}_{3}$ and suggest that the effects we observed were mainly due to bacterial membrane damage.

The molecular mechanisms behind the antibacterial effects of $\mathrm{HCO}_{3}{ }^{-}$are still unclear. We hypothesize that they might be due to the ability of $\mathrm{HCO}_{3}{ }^{-}$to chelate divalent cations $\left(\mathrm{Ca}^{2+}\right.$ and $\left.\mathrm{Mg}^{2+}\right)$. Lowering external divalent cation concentrations may increase bacterial membrane fragility and subsequently decrease viability. Indeed, divalent cations are known to maintain bacterial outer membrane integrity $[38,39]$. Not surprisingly, therefore, EDTA has inhibitory effects on the growth and biofilm formation of S. aureus [40-42]. In our experiments, EDTA enhanced SYTO9 entry into $P$. aeruginosa, which is probably due to outer membrane destabilization and increased 
permeability [43]. It has also been suggested that $\mathrm{HCO}_{3}{ }^{-}$may dissipate the proton gradient across the bacterial membrane, which could also decrease bacterial viability [44]. Although our data suggest that increased osmolarity did not contribute to the inhibitory effects of $\mathrm{HCO}_{3}{ }^{-}$, we do not exclude the possibility that $\mathrm{NaHCO}_{3}{ }^{-}$containing hypertonic solutions might have antibacterial effects, as has been observed with hypertonic saline [45].

The inhibitory effects of $100 \mathrm{mM} \mathrm{HCO}_{3}{ }^{-}$exceeded those of $25 \mathrm{mM} \mathrm{HCO}_{3}{ }^{-}$after $6 \mathrm{~h}$ of incubation, but not after $17 \mathrm{~h}$, where both concentrations were equally effective. We speculate that during the longer incubations, some loss of $\mathrm{HCO}_{3}{ }^{-}$may have occurred. Therefore, coupled with the fact that $\mathrm{HCO}_{3}{ }^{-}$is bacteriostatic rather than bactericidal [19], bacteria may recover from the temporary growth inhibition. Our CFU assays and flow cytometry data also showed that the lower concentration of $\mathrm{HCO}_{3}{ }^{-}(25 \mathrm{mM})$ reduced the growth of $P$. aeruginosa but not $S$. aureus, suggesting that bacterial species may have differing susceptibilities to $\mathrm{HCO}_{3}{ }^{-}$.

In the CF lung, bacterial biofilm formation presents major challenges for clinicians. Since we have previously shown that $\mathrm{HCO}_{3}{ }^{-}$inhibits $P$. aeruginosa biofilm formation in bouillon supplemented with $2 \%$ glucose, we here investigated its effects in ASM. Under these conditions, both 25 and $100 \mathrm{mM}$ $\mathrm{NaHCO}_{3}$ significantly inhibited biofilm formation, thus strengthening the clinical relevance of our previous observations [19]. Interestingly, we detected a significant increase in P. aeruginosa biofilm formation in alkaline ( $\mathrm{pH}$ 8.0) $\mathrm{NaHCO}_{3}$-free ASM. This observation is consistent with previous findings showing that $\mathrm{pH}$ influences biofilm formation [46,47]. However, despite the stimulatory effect of $\mathrm{pH}$ 8.0 on P. aeruginosa in the absence of $\mathrm{HCO}_{3}{ }^{-}$, the ASM containing $100 \mathrm{mM} \mathrm{NaHCO}$, also $\mathrm{pH} 8.0$, caused a marked inhibition of biofilm growth. This indicates that the more powerful antibacterial effect of $100 \mathrm{mM} \mathrm{HCO}_{3}{ }^{-}$can override any effects of the accompanying $\mathrm{pH}$ change.

In conclusion, we have demonstrated that $\mathrm{HCO}_{3}{ }^{-}$, and not raised $\mathrm{pH}$ or osmolarity inhibits both the growth and biofilm formation of prevalent $\mathrm{CF}$ bacteria grown in an artificial sputum medium whose composition resembles viscous CF mucus. It seems likely that $\mathrm{HCO}_{3}{ }^{-}$increases the permeability of the bacterial membrane, thus reducing cell viability. Bicarbonate should, therefore, be considered a potentially valuable therapeutic agent in CF and other chronic airway diseases involving bacterial infections.

\section{Materials and Methods}

\subsection{Artificial Sputum Medium and Growth Conditions}

ASM was prepared from sterile stock solutions, with the final concentrations shown in Table 1. The mucin stock solution $(5 \%(w / v))$ was prepared with deionized water sterilized by autoclaving at $121^{\circ} \mathrm{C}$ for $30 \mathrm{~min}$. Salmon testis DNA and ferritin were dissolved in sterile deionized water. All other stock solutions were prepared and sterilized using $0.22 \mu \mathrm{m}$-pore syringe filters.

Table 1. ASM components and their final concentrations.

\begin{tabular}{ccc}
\hline Name & Stock Concentration & Final Concentration \\
\hline Mucin from porcine stomach & $5 \%(w / v)$ & $2 \%(w / v)$ \\
DNA sodium salt from salmon testes & $14 \mathrm{mg} / \mathrm{mL}$ & $1.4 \mathrm{mg} / \mathrm{mL}$ \\
Casein hydrolysate & $20 \mathrm{mg} / \mathrm{mL}$ & $5 \mathrm{mg} / \mathrm{mL}$ \\
Egg yolk emulsion & $1 \times$ & $0.005 \times$ \\
Ferritin & $1 \mathrm{mg} / \mathrm{mL}$ & $0.003 \mathrm{mg} / \mathrm{mL}$ \\
$\mathrm{NaCl}^{*}$ & $2 \mathrm{M}$ & 100,75, or $0 \mathrm{mM}$ \\
$\mathrm{NaHCO}_{3}{ }^{*}$ & $1 \mathrm{M}$ & 0,25, or $100 \mathrm{mM}$ \\
$\mathrm{KCl}^{\text {Glucose }}$ & $2 \mathrm{M}$ & $30 \mathrm{mM}$ \\
HEPES acid & $2 \mathrm{M}$ & $11 \mathrm{mM}$ \\
HEPES Na salt & $1 \mathrm{M}$ & $50 \mathrm{mM}$
\end{tabular}

ASM recipe is modified from Sriramulu et al. (2005) and Quinn et al. (2015) [22,29]. * Concentration of $\mathrm{NaCl}$ and $\mathrm{NaHCO}_{3}$ are varied depending on the ASM conditions (Table 2). 
Table 2. ASM conditions and modifications.

\begin{tabular}{|c|c|c|c|c|c|c|}
\hline Test & Conditions & $\mathrm{pH}$ & DNA & $\begin{array}{l}\mathrm{NaCl} \\
(\mathrm{mM})\end{array}$ & $\begin{array}{l}\mathrm{NaHCO}_{3} \\
(\mathrm{mM})\end{array}$ & $\begin{array}{l}\text { Atmospheric } \\
\text { Condition }\end{array}$ \\
\hline \multirow{4}{*}{$\begin{array}{l}\text { CFU and biofilm } \\
\text { experiments }\end{array}$} & (1) $\mathrm{NaHCO}_{3}$-free ASM & 7.4 & Present & 100 & - & Ambient air \\
\hline & (2) $\mathrm{NaHCO}_{3}$-free ASM & 8.0 & Present & 100 & - & Ambient air \\
\hline & (3) $25 \mathrm{mM} \mathrm{NaHCO} 3-\mathrm{ASM}$ & 7.4 & Present & 75 & 25 & $5 \% \mathrm{CO}_{2}$ \\
\hline & (4) $100 \mathrm{mM} \mathrm{NaHCO}$-ASM & 8.0 & Present & - & 100 & $5 \% \mathrm{CO}_{2}$ \\
\hline \multirow{4}{*}{ Flow cytometry } & (1) $\mathrm{NaHCO}_{3}$-free ASM & 7.4 & Absent & 100 & - & Ambient air \\
\hline & (2) $\mathrm{NaHCO}_{3}$-free ASM & 8.0 & Absent & 100 & - & Ambient air \\
\hline & (3) $25 \mathrm{mM} \mathrm{NaHCO}-\mathrm{ASM}$ & 7.4 & Absent & 75 & 25 & $5 \% \mathrm{CO}_{2}$ \\
\hline & (4) $100 \mathrm{mM} \mathrm{NaHCO} 3-\mathrm{ASM}$ & 8.0 & Absent & - & 100 & $5 \% \mathrm{CO}_{2}$ \\
\hline
\end{tabular}

Artificial sputum media were prepared with and without $\mathrm{HCO}_{3}{ }^{-}$(Table 2). Please note that the ASM used in the flow cytometry experiments did not contain DNA because SYTO9 and PI, being nucleic acid stains, would bind to extracellular DNA.

The $\mathrm{pH}$ of the $\mathrm{NaHCO}_{3}$-free ASM was adjusted by mixing appropriate volumes of the HEPES acid and Na-HEPES stock solutions. For the $\mathrm{NaHCO}_{3}$-containing ASMs, the components of $\mathrm{NaCl}$ were reduced to maintain isosmotic conditions. Thus the $\mathrm{NaCl}$ concentration was reduced to $75 \mathrm{mM}$ in the ASM containing $25 \mathrm{mM} \mathrm{NaHCO}_{3}$, and to zero in the ASM containing $100 \mathrm{mM} \mathrm{NaHCO}$. Both of the $\mathrm{NaHCO}_{3}$-containing ASMs were incubated in $5 \% \mathrm{CO}_{2}$ giving $\mathrm{pH} 7.4$ and 8.0, respectively. Since $\mathrm{NaHCO}_{3}$ is heat-sensitive, $0.22 \mu \mathrm{m}$-pore syringe filters were used to sterilize the $\mathrm{NaHCO}_{3}$ stock solution. Furthermore, $\mathrm{NaHCO}_{3}$ was added to each ASM immediately prior to bacterial inoculation.

\subsection{Bacterial Strains}

Staphylococcus aureus (ATCC ${ }^{\circledR} 29213^{\mathrm{TM}}$ ) and Pseudomonas aeruginosa (ATCC ${ }^{\circledR} 27853^{\mathrm{TM}}$ ) were used in this study. Colony-forming unit (CFU) assays were also carried out with clinical isolates of the same bacterial species (S. aureus SA-113 and P. aeruginosa 17808). The pre-culture of each bacterium was prepared for each individual experiment from the same stock culture stored at $-80^{\circ} \mathrm{C}$. Bacteria were plated onto simple agar plates and incubated overnight. Single colonies were then picked to inoculate into 15-mL tubes containing $5 \mathrm{~mL}$ BHI broth (Mast Group Ltd., Merseyside, UK) and cultured overnight at $37^{\circ} \mathrm{C}$. The density of the cultures was adjusted with a VITEK Densichek apparatus (Biomérieux, Marcy l' Étoile, France) directly before using them for the experiments.

\subsection{Growth Experiments}

\subsubsection{Colony-Forming Unit Assay}

Overnight cultures of the bacteria were adjusted to $3.0 \mathrm{McF}$ arland (approximately $9.0 \times 10^{8} \mathrm{cells} / \mathrm{mL}$ ) and subcultured at a 1:50 dilution into ASM and mixed gently. $200 \mu \mathrm{L}$ aliquots of each suspension were dispensed into 96-well plates in triplicate and incubated at $37^{\circ} \mathrm{C}$ in ambient air (ASM without $\mathrm{NaHCO}_{3}$ ) or $5 \% \mathrm{CO}_{2}$ (ASM with either 25 or $100 \mathrm{mM} \mathrm{NaHCO}_{3}$ ) (Table 2). After 6 or $17 \mathrm{~h}$ incubation, $30 \mu \mathrm{L}$ of the bacterial culture was taken and serially diluted over a range of dilution factors from $10^{-1}$ to $10^{-9}$. Then $10 \mu \mathrm{L}$ aliquots of each dilution were plated onto simple agar plates, which were incubated overnight at $37^{\circ} \mathrm{C}$. The colonies on each plate were counted using ImageJ software $(\mathrm{NIH}$, Bethesda, MD, USA). Only plates that showed between 25 and 250 colonies were selected, and the colony densities $(\mathrm{CFU} / \mathrm{mL})$ were calculated using the following equation:

$$
\mathrm{CFU} / \mathrm{mL}=(\text { number of counts on the plate }) /(0.01 \times \text { dilution factor })
$$

Results in CFU/mL were then converted to a logarithmic scale (log CFU/mL). In each condition, three independent experiments were carried out $(n=3)$. All data were pooled (totaling 9 replicates per 
treatment group, except for S. aureus ATCC at $6 \mathrm{~h}$ having only 3 replicates). The mean values of $\log$ $\mathrm{CFU} / \mathrm{mL}$ in each condition were compared as designated.

\subsubsection{Flow Cytometry}

Bacterial Cultures and Sample Preparation before Staining

Overnight cultures were adjusted to 3.0 McFarland and subcultured at a 1:50 dilution into DNA-free ASM. $200 \mu \mathrm{L}$ aliquots of each suspension were dispensed into sterile $1.5-\mathrm{mL}$ tubes in triplicate and subsequently incubated for $17 \mathrm{~h}$ at $37^{\circ} \mathrm{C}$ in ambient air or $5 \% \mathrm{CO}_{2}$. After incubation, $0.85 \% \mathrm{NaCl}$ solution $(1 \mathrm{~mL}$ ) was added to each tube, which was then centrifuged at $12,000 \mathrm{rpm}$ for $2 \mathrm{~min}$ at room temperature (RT). The pellet was re-suspended in $1 \mathrm{~mL} 0.85 \% \mathrm{NaCl}$ solution and incubated for $10 \mathrm{~min}$ at RT. This step was repeated twice to remove excess ASM. Each bacterial suspension was then adjusted with $0.85 \% \mathrm{NaCl}$ solution to $0.5 \mathrm{McFarland}$ (approx. $1.5 \times 10^{8}$ cells $/ \mathrm{mL}$ ). In experiments with P. aeruginosa, EDTA ( $5 \mathrm{mM}$ ) was added to the saline solution to disrupt the outer membranes of the bacteria and to facilitate penetration of the dye [36].

Staining Procedure

Bacterial suspensions were stained with the LIVE/DEAD BacLight Bacteria Viability Kit (L7007, Invitrogen, Waltham, MA, USA). The BacLight consists of SYTO9, a membrane-permeant dye penetrating all cells, and PI, which is cell-impermeant and only enters damaged or dead cells. The staining reagent was prepared according to the manufacturer's instructions. Briefly, component A (1.67 mM SYTO9/1.67 mM PI) and component B (1.67 mM SYTO9/18.3 mM PI) were mixed 1:1 in a microtube. Five microliters of the mixture was added to $1 \mathrm{~mL}$ of each bacterial suspension $(5 \mu \mathrm{L} / \mathrm{mL}$ final concentration). The suspensions were subsequently mixed thoroughly and incubated in the dark for $25 \mathrm{~min}$ before measurement at RT. Microbeads (100 $\mu \mathrm{L}$ ) (Invitrogen, USA) were added to the suspensions for cell quantification. Samples containing ASM without bacteria were prepared and stained to verify background noise. The autofluorescence of the bacteria was assessed using unstained cells, and positive controls were generated by pre-treating the cells with propanol $(70 \%(v / v))$ to cause membrane damage, maximizing PI penetration. Therefore, the membrane-damaged or dead cells were simply detected with the high intensity of PI.

Flow Cytometric Measurement

Flow cytometry was carried out using a BD FACSCalibur system (Becton Dickinson, San Jose, CA, USA) equipped with a 635-nm red diode laser and a $15-\mathrm{mW} 488-\mathrm{nm}$ air-cooled argon solid-state laser. Forward scatter (FSC) and side scatter (SSC) were collected from the $488 \mathrm{~nm}$ excitation. SSC was set as a discriminator to reduce electronic background noise during the analysis.

The instrument settings were defined by the Megamix-Plus SSC beads (Biocytex, Marseille, France) and were optimized with $1 \mu \mathrm{m}$ Silica Beads Fluo-Green Green (Kisker Biotech GmbH \& Co., Steinfurt, Germany). Stained bacteria were excited by the 488-nm laser, and the fluorescence was collected through a 530/30-nm bandpass filter (SYTO9) and a 670-nm long-pass filter (PI). All signals were amplified logarithmically (four decades). The sampling rate was adjusted to less than 1000 particles/s. Each measurement lasted $1 \mathrm{~min}$. Sterile PBS was applied as a sheath fluid. Data were acquired with BD CellQuest Pro software (Becton Dickinson, San Jose, CA, USA). Stained cell suspensions were analyzed immediately after dye incubation.

Flow Cytometry Data Analysis

Data gating and analysis were performed using Flowing software version 2.5.1 (Turku Centre for Biotechnology, Turku, Finland, released 4.11.2013). Dot plots of detected signals from each sample were analyzed based on the FSC, SSC, green (FL1), and red (FL3) fluorescence intensities (Figure 6). 

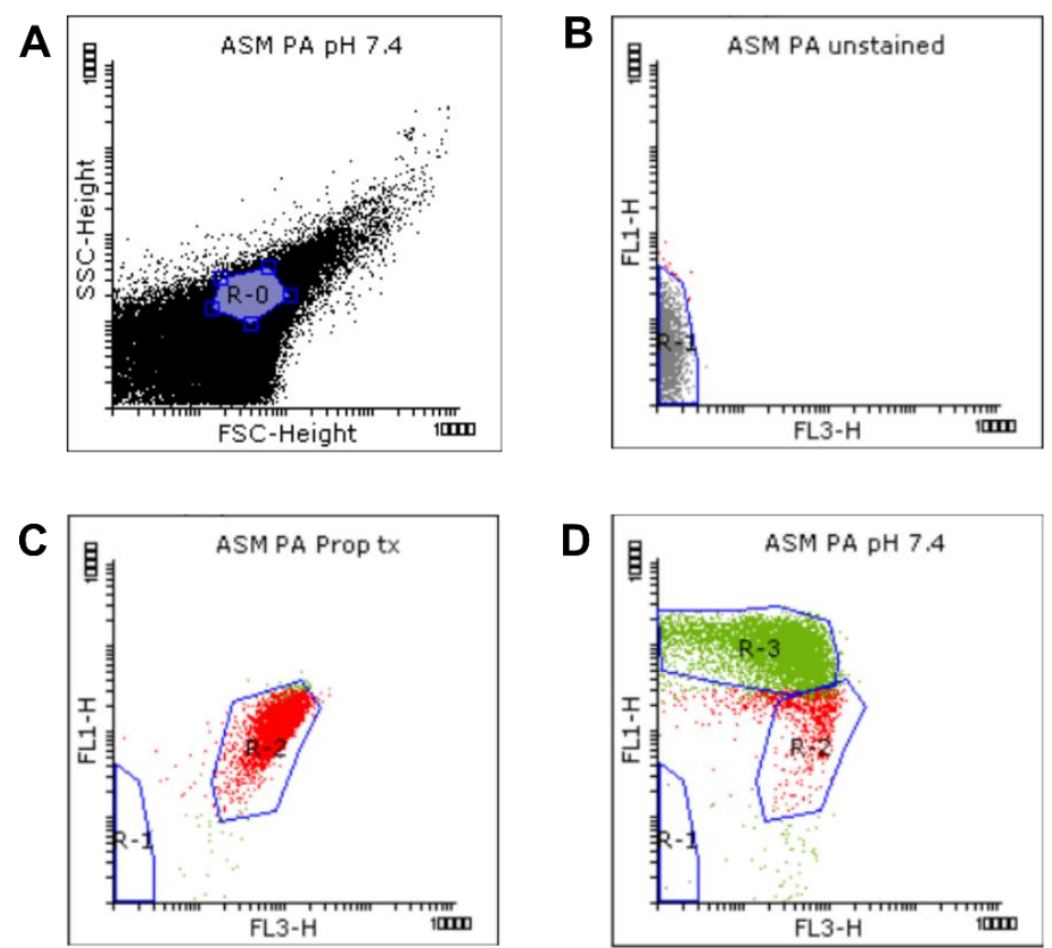

Figure 6. Gating strategy for the flow cytometric measurement. Viability was determined by membrane integrity analysis using the LIVE/DEAD BacLight Bacteria Viability Kit. We defined a standardized bacterial gate (R-0) (A) on the FSC-SSC dot plot, on the basis of the Megamix-SSC boundary. The bacterial signals inside the R-0 gate of the unstained (B), propanol-treated $(\mathbf{C})$, and untreated $\left(\mathrm{NaHCO}_{3}\right.$-free) samples (D) were analyzed based on the FL1 vs. FL3 fluorescence. Autofluorescence signals were gated in R-1. Signals with high FL3 intensity were gated in R-2. Signals with high FL1 intensity were gated in R-3.

A standardized bacterial gate (R-0) was set on the FSC-SSC dot plot, based on the Megamix-SSC boundary, to select the bacterial population (purple, Figure 6A). This bacterial R-0 gate was then saved and applied to other samples. Next, the unstained, propanol-treated, and untreated $\left(\mathrm{NaHCO}_{3}\right.$-free) samples were analyzed to determine the regions of autofluorescence, dead and living cells, respectively (Figure 6B-D). Briefly, signals detected from the unstained sample were identified first and attributed to autofluorescence and background noise. They were subsequently gated in R-1 (grey, Figure 6B) to discriminate them from bacterial signals. Next, the positive control and untreated samples were analyzed. Signals with high intensities in FL1 and FL3 (SYTO9- and PI-positive signals, respectively) were selected and attributed to bacterial cells (Figure 6C,D). For the determination of bacterial viability, manually set gates were applied based on the positive control and untreated samples. Since the positive control samples were treated $70 \%$ propanol in order to kill the bacteria, the signals detected from this sample, exhibiting a high intensity in FL3, were attributed to membrane-damaged or dead cells, and gated in the R-2 region (red, Figure 6C). This R-2 gate was next applied to the untreated samples, where signals outside the R-2 gate, which exhibited a high intensity in FL1, were gated in the R-3 region (green, Figure 6D) and attributed to membrane-intact or healthy cells. The presets of these R-regions were saved as a template and then applied to the other samples using the automated folder runner function to obtain the data from each sample.

Frequencies of the signals inside the R-2 and R-3 gates from each condition were quantified using the statistic function of the software and presented as percentages of the total population in R-0. Three (P. aeruginosa) and four (S. aureus) independent experiments were performed. All data were pooled (totaling 9-12 replicates per treatment group). Means of the percentages of SYTO9- and 
PI-positive signals, and the ratio of SYTO9- to PI-positive signals were compared in ASM with and without $\mathrm{NaHCO}_{3}$.

\subsection{Biofilm Crystal Violet Assay}

Bacterial suspensions of P. aeruginosa 17808 (clinical isolate) were prepared following the same protocol as described for the CFU assays. $200 \mu \mathrm{L}$ of each suspension was dispensed into 96-well plates in five duplicates. Bacteria were incubated in ambient air (ASM without $\mathrm{NaHCO}_{3}$ ) or $5 \% \mathrm{CO}_{2}$ (ASM with either 25 or $100 \mathrm{mM} \mathrm{NaHCO} 3$ ) for $48 \mathrm{~h}$ at $37^{\circ} \mathrm{C}$. After incubation, unattached bacteria were removed by rigorous washing with $200 \mu \mathrm{L}$ of $1 \times$ PBS three times. Bacteria attached to the wells were air-dried and subsequently stained with $125 \mu \mathrm{L}$ crystal violet solution $(0.1 \%)$ for $10 \mathrm{~min}$. Excess crystal violet was removed by rinsing the plates several times in tap water. The plates were then air-dried. Crystal violet stain was solubilized in 30\% acetic acid ( $200 \mu \mathrm{L} /$ well) for $10 \mathrm{~min}$. From each well, $125 \mu \mathrm{L}$ of this solution was taken and transferred to a new flat-bottom 96-well plate (Figure 5A). Optical density (OD) was measured at $595 \mathrm{~nm}$ in a PR2100 microplate reader. The average OD from the control ASM wells without bacteria was subtracted from the ODs measured in wells with bacteria. Three independent experiments were performed $(n=3)$. All data were pooled (totaling 15 replicates per treatment group). Means of OD in each condition were compared in the ASM with and without $\mathrm{NaHCO}_{3}$.

\subsection{Statistical Analysis}

The statistical analysis was performed on the pooled data of each experimental group, except for S. aureus ATCC 29213 CFU assay at 6 h, by using GraphPad Prism version 8.0.0 (GraphPad Software, Inc., San Diego, CA, USA). Pooled data were normally distributed (Shapiro-Wilk test) and presented as means \pm SD. The means were compared using one-way ANOVA, followed by Tukey's post-hoc multiple comparison test. The un-pooled data were analyzed by using Kruskal-Wallis test, followed by Dunn's post-hoc multiple comparison test. Changes were considered statistically significant if $p<0.05$.

Author Contributions: Conceptualization, M.S., Z.L., O.D. and Á.Z.; methodology, P.J., K.R., B.S. and É.P.; investigation, P.J., K.R., B.S. and É.P.; data analysis, P.J. and É.P.; writing—original draft preparation, P.J., O.D. and Á.Z.; writing一review and editing, P.J., M.S., Z.L., O.D. and Á.Z.; funding acquisition, Z.L., O.D. and Á.Z. All authors have read and agreed to the published version of the manuscript.

Funding: This work was supported by the Hungarian Human Resources Development Operational Program (Grant No. EFOP-3.6.2-16-2017-00006).

Acknowledgments: We thank Kristóf Kádár for his help in statistical analysis.

Conflicts of Interest: The authors declare no conflict of interest.

\section{References}

1. Riordan, J.R.; Rommens, J.M.; Kerem, B.; Alon, N.; Rozmahel, R.; Grzelczak, Z.; Zielenski, J.; Lok, S.; Plavsic, N.; Chou, J.L.; et al. Identification of the cystic fibrosis gene: Cloning and characterization of complementary DNA. Science 1989, 245, 1066-1073. [CrossRef] [PubMed]

2. $\quad$ Linsdell, P.; Tabcharani, J.A.; Rommens, J.M.; Hou, Y.X.; Chang, X.B.; Tsui, L.C.; Riordan, J.R.; Hanrahan, J.W. Permeability of wild-type and mutant cystic fibrosis transmembrane conductance regulator chloride channels to polyatomic anions. J. Gen. Physiol. 1997, 110, 355-364. [CrossRef] [PubMed]

3. Reddy, M.M.; Quinton, P.M. Control of dynamic CFTR selectivity by glutamate and ATP in epithelial cells. Nature 2003, 423, 756-760. [CrossRef] [PubMed]

4. Livraghi-Butrico, A.; Kelly, E.J.; Wilkinson, K.J.; Rogers, T.D.; Gilmore, R.C.; Harkema, J.R.; Randell, S.H.; Boucher, R.C.; O'Neal, W.K.; Grubb, B.R. Loss of Cftr function exacerbates the phenotype of $\mathrm{Na}(+)$ hyperabsorption in murine airways. Am. J. Physiol. Lung Cell. Mol. Physiol. 2013, 304, L469-L480. [CrossRef] [PubMed]

5. Kunzelmann, K.; Schreiber, R.; Hadorn, H.B. Bicarbonate in cystic fibrosis. J. Cyst. Fibros. 2017, 16, 653-662. [CrossRef] [PubMed] 
6. Simonin, J.; Bille, E.; Crambert, G.; Noel, S.; Dreano, E.; Edwards, A.; Hatton, A.; Pranke, I.; Villeret, B.; Cottart, C.H.; et al. Airway surface liquid acidification initiates host defense abnormalities in Cystic Fibrosis. Sci. Rep. 2019, 9, 6516. [CrossRef]

7. Matsui, H.; Wagner, V.E.; Hill, D.B.; Schwab, U.E.; Rogers, T.D.; Button, B.; Taylor, R.M., 2nd; Superfine, R.; Rubinstein, M.; Iglewski, B.H.; et al. A physical linkage between cystic fibrosis airway surface dehydration and Pseudomonas aeruginosa biofilms. Proc. Natl. Acad. Sci. USA 2006, 103, 18131-18136. [CrossRef]

8. Lyczak, J.B.; Cannon, C.L.; Pier, G.B. Lung infections associated with cystic fibrosis. Clin. Microbiol. Rev. 2002, 15, 194-222. [CrossRef]

9. McDaniel, C.; Panmanee, W.; Hassett, D.J. An Overview of Infections in Cystic Fibrosis Airways and the Role of Environmental Conditions on Pseudomonas aeruginosa Biofilm Formation and Viability. In Cystic Fibrosis in the Light of New Research; Wat, D., Ed.; IntechOpen: London, UK, 2015; pp. 171-199.

10. Boucher, R.C. An overview of the pathogenesis of cystic fibrosis lung disease. Adv. Drug Deliv. Rev. 2002, 54, 1359-1371. [CrossRef]

11. Quinton, P.M. Cystic fibrosis: Impaired bicarbonate secretion and mucoviscidosis. Lancet 2008, 372, 415-417. [CrossRef]

12. Ermund, A.; Trillo-Muyo, S.; Hansson, G.C. Assembly, Release, and Transport of Airway Mucins in Pigs and Humans. Ann. Am. Thorac. Soc. 2018, 15, S159-S163. [CrossRef] [PubMed]

13. Birket, S.E.; Chu, K.K.; Liu, L.; Houser, G.H.; Diephuis, B.J.; Wilsterman, E.J.; Dierksen, G.; Mazur, M.; Shastry, S.; Li, Y.; et al. A functional anatomic defect of the cystic fibrosis airway. Am. J. Respir. Crit. Care Med. 2014, 190, 421-432. [CrossRef] [PubMed]

14. Birket, S.E.; Davis, J.M.; Fernandez, C.M.; Tuggle, K.L.; Oden, A.M.; Chu, K.K.; Tearney, G.J.; Fanucchi, M.V.; Sorscher, E.J.; Rowe, S.M. Development of an airway mucus defect in the cystic fibrosis rat. JCI Insight 2018, 3, e97199. [CrossRef]

15. Garcia, M.A.; Yang, N.; Quinton, P.M. Normal mouse intestinal mucus release requires cystic fibrosis transmembrane regulator-dependent bicarbonate secretion. J Clin. Investig. 2009, 119, 2613-2622. [CrossRef] [PubMed]

16. Gustafsson, J.K.; Ermund, A.; Ambort, D.; Johansson, M.E.; Nilsson, H.E.; Thorell, K.; Hebert, H.; Sjövall, H.; Hansson, G.C. Bicarbonate and functional CFTR channel are required for proper mucin secretion and link cystic fibrosis with its mucus phenotype. J. Exp. Med. 2012, 209, 1263-1272. [CrossRef] [PubMed]

17. Pezzulo, A.A.; Tang, X.X.; Hoegger, M.J.; Abou Alaiwa, M.H.; Ramachandran, S.; Moninger, T.O.; Karp, P.H.; Wohlford-Lenane, C.L.; Haagsman, H.P.; van Eijk, M.; et al. Reduced airway surface pH impairs bacterial killing in the porcine cystic fibrosis lung. Nature 2012, 487, 109-113. [CrossRef] [PubMed]

18. Gróf, I.; Bocsik, A.; Harazin, A.; Santa-Maria, A.R.; Vizsnyiczai, G.; Barna, L.; Kiss, L.; Fûr, G.; Rakonczay, Z., Jr.; Ambrus, R.; et al. The Effect of Sodium Bicarbonate, a Beneficial Adjuvant Molecule in Cystic Fibrosis, on Bronchial Epithelial Cells Expressing a Wild-Type or Mutant CFTR Channel. Int. J. Mol. Sci. 2020, 21, 4024. [CrossRef]

19. Dobay, O.; Laub, K.; Stercz, B.; Kéri, A.; Balázs, B.; Tóthpál, A.; Kardos, S.; Jaikumpun, P.; Ruksakiet, K.; Quinton, P.M.; et al. Bicarbonate Inhibits Bacterial Growth and Biofilm Formation of Prevalent Cystic Fibrosis Pathogens. Front. Microbiol. 2018, 9, 2245. [CrossRef]

20. Ghani, M.; Soothill, J.S. Ceftazidime, gentamicin, and rifampicin, in combination, kill biofilms of mucoid Pseudomonas aeruginosa. Can. J. Microbiol. 1997, 43, 999-1004. [CrossRef]

21. Palmer, K.L.; Aye, L.M.; Whiteley, M. Nutritional cues control Pseudomonas aeruginosa multicellular behavior in cystic fibrosis sputum. J. Bacteriol. 2007, 189, 8079-8087. [CrossRef]

22. Sriramulu, D.D.; Lünsdorf, H.; Lam, J.S.; Römling, U. Microcolony formation: A novel biofilm model of Pseudomonas aeruginosa for the cystic fibrosis lung. J. Med. Microbiol. 2005, 54, 667-676. [CrossRef] [PubMed]

23. Kirchner, S.; Fothergill, J.L.; Wright, E.A.; James, C.E.; Mowat, E.; Winstanley, C. Use of artificial sputum medium to test antibiotic efficacy against Pseudomonas aeruginosa in conditions more relevant to the cystic fibrosis lung. J. Vis. Exp. 2012, e3857. [CrossRef] [PubMed]

24. Thomas, S.R.; Ray, A.; Hodson, M.E.; Pitt, T.L. Increased sputum amino acid concentrations and auxotrophy of Pseudomonas aeruginosa in severe cystic fibrosis lung disease. Thorax 2000, 55, 795-797. [CrossRef] [PubMed]

25. Fung, C.; Naughton, S.; Turnbull, L.; Tingpej, P.; Rose, B.; Arthur, J.; Hu, H.; Harmer, C.; Harbour, C.; Hassett, D.J.; et al. Gene expression of Pseudomonas aeruginosa in a mucin-containing synthetic growth medium mimicking cystic fibrosis lung sputum. J. Med. Microbiol. 2010, 59, 1089-1100. [CrossRef] [PubMed] 
26. Yeung, A.T.; Parayno, A.; Hancock, R.E. Mucin promotes rapid surface motility in Pseudomonas aeruginosa. mBio 2012, 3, e00073-12. [CrossRef] [PubMed]

27. Behrends, V.; Geier, B.; Williams, H.D.; Bundy, J.G. Direct assessment of metabolite utilization by Pseudomonas aeruginosa during growth on artificial sputum medium. Appl. Environ. Microbiol. 2013, 79, 2467-2470. [CrossRef]

28. Wright, E.A.; Fothergill, J.L.; Paterson, S.; Brockhurst, M.A.; Winstanley, C. Sub-inhibitory concentrations of some antibiotics can drive diversification of Pseudomonas aeruginosa populations in artificial sputum medium. BMC Microbiol. 2013, 13, 170. [CrossRef]

29. Quinn, R.A.; Whiteson, K.; Lim, Y.W.; Salamon, P.; Bailey, B.; Mienardi, S.; Sanchez, S.E.; Blake, D.; Conrad, D.; Rohwer, F. A Winogradsky-based culture system shows an association between microbial fermentation and cystic fibrosis exacerbation. ISME J. 2015, 9, 1024-1038. [CrossRef]

30. Davies, E.V.; James, C.E.; Brockhurst, M.A.; Winstanley, C. Evolutionary diversification of Pseudomonas aeruginosa in an artificial sputum model. BMC Microbiol. 2017, 17, 3. [CrossRef]

31. Corral, L.G.; Post, L.S.; Montville, T.J. Antimicrobial Activity of Sodium Bicarbonate. J. Food Sci. 1988, 53, 981-982. [CrossRef]

32. Xie, C.; Tang, X.; Xu, W.; Diao, R.; Cai, Z.; Chan, H.C. A host defense mechanism involving CFTR-mediated bicarbonate secretion in bacterial prostatitis. PLoS ONE 2010, 5, e15255. [CrossRef] [PubMed]

33. Letscher-Bru, V.; Obszynski, C.M.; Samsoen, M.; Sabou, M.; Waller, J.; Candolfi, E. Antifungal activity of sodium bicarbonate against fungal agents causing superficial infections. Mycopathologia 2013, 175, 153-158. [CrossRef] [PubMed]

34. Grégori, G.; Citterio, S.; Ghiani, A.; Labra, M.; Sgorbati, S.; Brown, S.; Denis, M. Resolution of viable and membrane-compromised bacteria in freshwater and marine waters based on analytical flow cytometry and nucleic acid double staining. Appl. Environ. Microbiol. 2001, 67, 4662-4670. [CrossRef] [PubMed]

35. Hoefel, D.; Grooby, W.L.; Monis, P.T.; Andrews, S.; Saint, C.P. Enumeration of water-borne bacteria using viability assays and flow cytometry: A comparison to culture-based techniques. J. Microbiol. Methods 2003, 55, 585-597. [CrossRef]

36. Berney, M.; Hammes, F.; Bosshard, F.; Weilenmann, H.U.; Egli, T. Assessment and interpretation of bacterial viability by using the LIVE/DEAD BacLight Kit in combination with flow cytometry. Appl. Environ. Microbiol. 2007, 73, 3283-3290. [CrossRef] [PubMed]

37. Stiefel, P.; Schmidt-Emrich, S.; Maniura-Weber, K.; Ren, Q. Critical aspects of using bacterial cell viability assays with the fluorophores SYTO9 and propidium iodide. BMC Microbiol. 2015, 15, 36. [CrossRef]

38. Thomas, K.J., 3rd; Rice, C.V. Revised model of calcium and magnesium binding to the bacterial cell wall. Biometals 2014, 27, 1361-1370. [CrossRef]

39. Clifton, L.A.; Skoda, M.W.; Le Brun, A.P.; Ciesielski, F.; Kuzmenko, I.; Holt, S.A.; Lakey, J.H. Effect of divalent cation removal on the structure of gram-negative bacterial outer membrane models. Langmuir 2015, 31, 404-412. [CrossRef]

40. Walsh, S.E.; Maillard, J.Y.; Russell, A.D.; Catrenich, C.E.; Charbonneau, D.L.; Bartolo, R.G. Activity and mechanisms of action of selected biocidal agents on Gram-positive and -negative bacteria. J. Appl. Microbiol. 2003, 94, 240-247. [CrossRef]

41. Sharma, M.; Visai, L.; Bragheri, F.; Cristiani, I.; Gupta, P.K.; Speziale, P. Toluidine blue-mediated photodynamic effects on staphylococcal biofilms. Antimicrob. Agents Chemother. 2008, 52, 299-305. [CrossRef]

42. Finnegan, S.; Percival, S.L. EDTA: An Antimicrobial and Antibiofilm Agent for Use in Wound Care. Adv. Wound Care (New Rochelle) 2015, 4, 415-421. [CrossRef] [PubMed]

43. Alakomi, H.L.; Paananen, A.; Suihko, M.L.; Helander, I.M.; Saarela, M. Weakening effect of cell permeabilizers on gram-negative bacteria causing biodeterioration. Appl. Environ. Microbiol. 2006, 72, 4695-4703. [CrossRef] [PubMed]

44. Farha, M.A.; French, S.; Stokes, J.M.; Brown, E.D. Bicarbonate Alters Bacterial Susceptibility to Antibiotics by Targeting the Proton Motive Force. ACS Infect Dis. 2018, 4, 382-390. [CrossRef] [PubMed]

45. Reeves, E.P.; Molloy, K.; Pohl, K.; McElvaney, N.G. Hypertonic saline in treatment of pulmonary disease in cystic fibrosis. Sci. World J. 2012, 2012, 465230. [CrossRef] [PubMed] 
46. Hostacká, A.; Ciznár, I.; Stefkovicová, M. Temperature and pH affect the production of bacterial biofilm. Folia. Microbiol. (Praha) 2010, 55, 75-78. [CrossRef]

47. Rasamiravaka, T.; Randrianierenana, A.L.; Raherimamdimby, M.; Andrianarisoa, B. Effect of pH on biofilm formation and motilities of Pseudomonas aeruginosa, Escherichia coli and Staphylococcus aureus ATCC strains. BMR Microbiol. 2018, 4, 1-5.

Publisher's Note: MDPI stays neutral with regard to jurisdictional claims in published maps and institutional affiliations.

(C) 2020 by the authors. Licensee MDPI, Basel, Switzerland. This article is an open access article distributed under the terms and conditions of the Creative Commons Attribution (CC BY) license (http://creativecommons.org/licenses/by/4.0/). 